\title{
Deficiency of non-suppressible insulin-like activity in thalassaemia major
}

\author{
G A WERTHER, RAE MATTHEWS, H G BURGER, AND A C HERINGTON
}

Medical Research Centre, Prince Henry's Hospital, Haematology Clinic, Queen Victoria Medical Centre, and Haematology Clinic, Royal Children's Hospital, Melbourne, Australia

SUMMARY The commonly occurring short stature in the condition of thalassaemia major was investigated with respect to the possible role of the somatomedin growth factor low molecular weight non-suppressible insulin-like activity (NSILAs). Nineteen affected patients (12 boys, 7 girls) aged between 2 and 21 years were studied. Twelve of them were on or below the 10th centile for height, of whom 7 were on or below the 3rd centile for height. Serum immunoreactive growth hormone responses to exercise were normal in 9 of 11 subjects tested. Using an isolated fat cell bioassay NSILAs was undetectable in 10 and was more than 2 SD below the normal mean value in the other 9 subjects. High molecular weight NSILA (not a growth factor) was very low or undetectable in all 9 subjects tested. Low molecular weight NSILAs did not show the normal correlation with age in childhood, nor was there any correlation with height, height velocity, or bone age. The 2 children above the 50th centile for height had undetectable NSILAs. There was no evidence of iron or ferritin interfering in the bioassay, and mixing experiments showed no evidence of inhibitory activity towards NSILAs in thalassaemic sera. Low circulating levels of the somatomedin NSILAs may contribute to the short stature in thalassaemia major, but other factors may permit normal growth in some affected children.

Beta-thalassaemia major is a severe, recessively inherited disorder of haemoglobin synthesis. It presents in early life with anaemia and hepatosplenomegaly and is prevalent among Mediterranean groups in whom the carrier rate (thalassaemia minor) ranges from 5 to $10 \%{ }^{1}$ Blood transfusions are required every 4 to 8 weeks. In addition to shortened life span, principal problems in affected children are short stature and delayed puberty. Endocrine investigations in such children have shown an increased incidence of delayed bone age, ${ }^{2}$ gonadotrophin insufficiency, ${ }^{3}$ and impaired postpubertal adrenal responses to synthetic corticotrophin. ${ }^{4}$ Diabetes mellitus and hypoparathyroidism are occasionally found. ${ }^{5}$ Thyroid function and growth hormone $(\mathrm{GH})$ responses to provocative stimuli have been reported as normal. ${ }^{6}$ The short stature of such children has therefore not been explained adequately. The possible role of somatomedin-like growth factors ${ }^{7}$ in the short stature of such children has not been considered previously. This study was designed therefore to examine the levels of the growth factor non-suppressible insulin-like activity (NSILAs) in children with thalassaemia major.
Serum NSILA accounts for $90 \%$ of total insulinlike activity, being detected after neutralisation of immunoreactive insulin by anti-insulin antibody. ${ }^{8}$ NSILAs is the low molecular weight $(\sim 7000)$, acid-ethanol soluble component of NSILA and circulates bound to a carrier protein. It shares the growth-promoting properties of other somatomedins, and two molecular species with considerable structural homology have been defined. These have been renamed insulin-like growth factors I and II. ${ }^{8}$ Insulin-like growth factor $I$ is probably identical with one of the somatomedins, SmC. ${ }^{9} \mathrm{~A}$ high molecular weight NSILA $(\sim 90000)$ not soluble in acid-ethanol also circulates in serum and has insulin-like, but not growth-promoting properties. ${ }^{8}$

In this study, circulating low molecular weight NSILAs and high molecular weight NSILA were examined in a group of 19 subjects with thalassaemia major.

\section{Patients and methods}

Nineteen children and young adults with $\beta$ thalassaemia major took part in the study. There 
were 12 boys and 7 girls with ages ranging from 2 to 21 years, and all had been diagnosed within the first year of life. All children underwent blood transfusions every 4-8 weeks, under a transfusion regimen ${ }^{10}$ established 7 years before the study, to maintain their haemoglobin levels above $8 \mathrm{~g} / \mathrm{dl}$ and to raise them with each transfusion to $14 \mathrm{~g} / \mathrm{dl}$. Fifteen children were prepubertal, one of whom (a girl) was over 16 years of age. Twelve were on or below the 10th centile for height of whom 7 were on or below the 3rd centile for height. Height centiles were assessed according to the British norms of Tanner and Whitehouse ${ }^{11}$ since more appropriate norms for immigrant Mediterranean populations in Australia are not available. Parental heights were known for 10 children, of whom 6 were inappropriately short compared with their parents. ${ }^{12}$ One boy, aged 6 , who was below the 3 rd centile for height had an unaffected twin sister on the 50th centile for height.

Desferrioxamine, an iron-chelating agent, had been given to each child with every blood transfusion since diagnosis. Nine of the children had been started on a programme of intensive treatment with desferrioxamine by daily intramuscular injection during the previous 1 to 8 years. During the 4 months preceding this study these 9 children and another 6 were begun on an alternative regimen of daily desferrioxamine by nocturnal subcutaneous infusion.

The Table shows the results of investigations previously performed in some of the children. Bone age was delayed (by more than $1 \frac{1}{2}$ years) in 5 children (of 14 studied), and serum iron and ferritin levels were greatly increased in all children tested. Mild disturbances in liver function were noted in $\mathbf{1 2}$ of the 14 children tested, the most common abnormality being moderately raised aspartate transaminase levels. Serum proteins, including serum albumin, were normal in all except one child.

Exercise-induced GH stimulation tests were performed in 11 of the 19 children, blood samples being taken before, immediately after, and 20 minutes after vigorous exercise on a bicycle ergometer or running upstairs. Serum GH was estimated

Table Initial investigations performed in 19 patients studied with thalassaemia major

\begin{tabular}{|c|c|}
\hline $\begin{array}{l}\text { Bone age }{ }^{14} \\
\text { Serum ferritin } 13\end{array}$ & $\begin{array}{l}>18 \text { months delay in } 6 \\
2300-25000 \mu \mathrm{mol} / 1(1000-11000 \mu \mathrm{g} / \mathrm{l}) \\
\text { (normal: } 23-690 \mu \mathrm{mol} / 1 ; 10-300 \mu \mathrm{g} / 1)\end{array}$ \\
\hline Serum iron 6 & $\begin{array}{l}29-55 \mu \mathrm{mol} / 1(162-308 \mu \mathrm{g} / 100 \mathrm{ml}) \\
\text { (normal: } 10-30 \mu \mathrm{mol} / 1 ; 56-168 \mu \mathrm{g} / 100 \mathrm{ml} \text { ) }\end{array}$ \\
\hline Liver function tests ${ }^{14}$ & $\begin{array}{l}\text { Aspartate transaminase: } 10 \text { moderately } \\
\text { increased } \\
\text { Bilirubin: } 3 \text { moderately increased } \\
\text { Protein: } 1 \text { low } \\
\text { Alkaline phosphatase: } 1 \text { high } \\
9 \text { normal responses }(>20 \mathrm{mU} / 1)\end{array}$ \\
\hline
\end{tabular}

by a radioimmunoassay using polyethylene glycol to $?$ precipitate antibody-bound hormone. For measure-⿳亠丷厂․ ment of NSILA, $10-20 \mathrm{ml}$ of blood was collected $\Rightarrow$ from each child immediately before transfusion. $\stackrel{\text { ? }}{\rightarrow}$ Serum was separated and stored at $-20^{\circ} \mathrm{C}$ for up to을 3 months before assay. NSILA was estimated by $a \frac{\overline{\bar{N}}}{\bar{N}}$ previously described bioassay ${ }^{13}$ using the incorpor- $-\frac{}{D}$ ation of ${ }^{14} \mathrm{C}$-glucose into isolated rat adipocytes in $\stackrel{\varnothing}{\varnothing}$ the presence of excess anti-insulin antibody. Low molecular weight NSILAs was estimated after an initial acid-ethanol extraction of serum samples. before incorporation in the bioassay. ${ }^{13}$ High $\vec{\omega}$ molecular weight NSILA was estimated by using unextracted but dialysed serum samples in the bioassay. Activity measured in these circumstances? is essentially that of the high molecular weight formo only. ${ }^{14}$ Results in both assays were expressed as $\overrightarrow{-}$ potencies compared with a similarly treated referenceoo pool of normal serum defined as $1 \mathrm{U} / \mathrm{ml}$. NSILAs was also estimated in a control group of 6 prepubertal윽 boys aged 14-16 years with constitutional shortstature. To test for the presence of inhibitors of $Z$ NSILA, mixing experiments were performed between thalassaemic sera or acid-ethanol extracts and similar $\stackrel{\mathcal{D}}{3}$ normal pool preparations. Equal volumes of dialysed preparations were mixed and reconstituted to the initial volume of each preparation before assay. this way concentrations were unaffected.

Iron was assayed by a colorimetric method, ${ }^{15}$ a ferritin was assayed by a solid phase, immuno-radiomimetric kit (Ramco Labs Inc, Texas) method.

\section{Results}

In order to exclude GH deficiency, exercise-induced $\overrightarrow{\overrightarrow{0}}$ GH stimulation tests were performed initially in 113 of the 19 children. The Table shows the results of exercise-induced GH stimulation tests. In 9 of the 11 . children tested, $\mathrm{GH}$ responses were normal, peak levels of greater than $20 \mathrm{mU} / 1$ being reached.

Fig. 1 shows that NSILAs was abnormally low in $\frac{1}{3}$ all 19 children with thalassaemia major, being undetectable in 10 of them. Similarly, high molecular weight NSILA was also very low or undetectable in the 9 affected children studied. Fig. 2a shows the relationship between NSILAs and age in the affected $>$ children. Duration of disease is closely related to age, as onset of symptoms is generally in the first year of N life. Low or undetectable levels of NSILAs occur at ${ }^{\circ}$ all ages and there is no evidence of an age-related 0 trend. Furthermore, affected children fail to show the ${ }^{N}$ normal pattern of increasing levels of NSILAs up to age 8 to 10 years. ${ }^{16}$ Fig. $2 \mathrm{~b}$ shows that there is also noo relationship between NSILAs and height centile in $\bar{\varnothing}$ the affected children, 2 children being above the 50th $\stackrel{\mathscr{S}}{+}$ centile despite undetectable NSILAs. All children on 0 


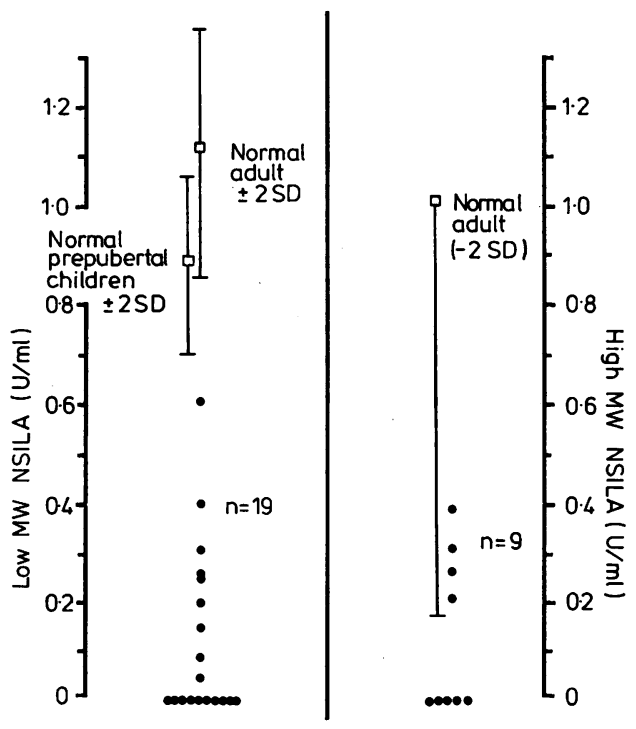

Fig. 1 Levels of low molecular weight NSILAs and high molecular weight NSILA in thalassaemia major. Low molecular weight NSILAs was measured in acid-ethanol extracts and compared with similar extracts from control sera. High molecular weight NSILA was measured in unextracted sera and compared with control sera. Results $(U / \mathrm{ml})$ are expressed in relation to a normal reference pool (defined $1 \mathrm{U} / \mathrm{ml}$ ). or below the 3rd height centile had undetectable or very low levels of NSILAs. Similarly there was no relationship between NSILAs and height velocity or bone age (not shown). The results of mixing experiments show no evidence for the presence of inhibitors of NSILAs, or NSILA in thalassaemic sera or acid-ethanol extracts respectively. The potency of the reference normal pool serum or extract (defined as $1 \mathrm{U} / \mathrm{ml}$ in each case) was not affected (serum $0.92,0.93 \mathrm{U} / \mathrm{ml}, \mathrm{n}=2$; extract $1.03 \pm 0.24$, mean $\pm \mathrm{SD}, \mathrm{n}=4$ ) by the addition respectively of thalassaemic sera (potency $0 \cdot 14,0.34 \mathrm{U} / \mathrm{ml}, \mathrm{n}=2$ ) or extracts $(0.07 \pm 0.05$, mean $\pm S D, n=4)$. The possible inhibitory effects of iron or ferritin were examined since, as expected, the sera of these thalassaemic children contained high levels of iron (29-55 $\mu \mathrm{mol} / \mathrm{l}(162-308 \mu \mathrm{g} / 100 \mathrm{ml})$; normal range 10-30 $\mu \mathrm{mol} / 1(56-168 \mu \mathrm{g} / 100 \mathrm{ml})$ ) and ferritin ( $>4500 \mu \mathrm{mol} / \mathrm{l}(>2000 \mu \mathrm{g} / \mathrm{l})$; normal range 45-410 $\mu \mathrm{mol} / 1(20-180 \mu \mathrm{g} / \mathrm{l}))$. Dialysis of unextracted sera had little effect on these levels. However, acidethanol extraction led to negligible levels of iron and low levels of ferritin $(270-1200 \mu \mathrm{mol} / 1 ; 120-540$ $\mu \mathrm{g} / \mathrm{l})$ in thalassaemic sera. Addition of ferritir $(1100 \mu \mathrm{mol} / \mathrm{l} ; 500 \mu \mathrm{g} / \mathrm{l})$ to normal serum extracts (potency $1 \mathrm{U} / \mathrm{ml}$, defined) however led to no change in measured NSILAs (potency $1.06 \mathrm{U} / \mathrm{ml}$ ).

\section{Discussion}

Short stature is common, although not universal, in thalassaemia major. Several studies have reported
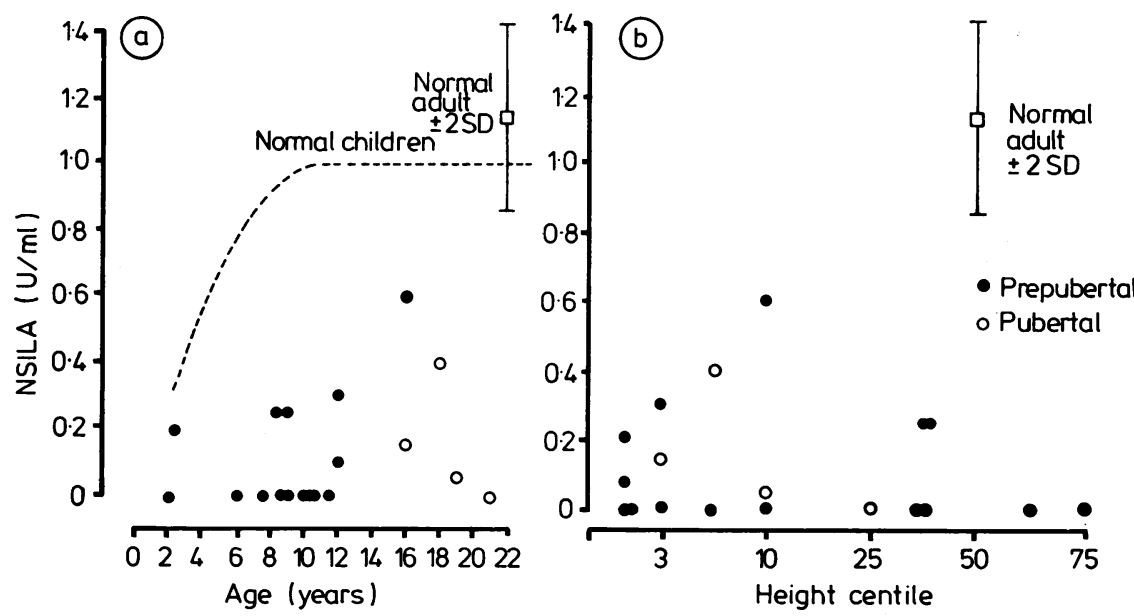

Fig. 2 Relationship of low molecular weight NSILAs with (a) age, and (b) height centile for all 19 patients with thalassaemia major. Dotted line in (a) shows the increase in NSILAs in sera with age in normal children. ${ }^{16}$ 
poor linear growth more commonly in association with delayed bone age and delayed puberty 6 suggesting a role for impaired gonadotrophin secretion in the short stature. ${ }^{3}$ This does not however account for short stature in affected younger children. In the present study, 14 of the 19 children were prepubertal without delayed puberty. Of these 14,6 were on or below the 3rd centile for height, and 6 were short compared with mid-parental height. Several studies have reported normal thyroid function tests and normal GH responses to provocative stimuli in affected children. ${ }^{6}$ In the present study 9 of 11 children tested showed normal GH responses to exercise. One normal child in 5 is also reported to show an inadequate $\mathrm{GH}$ response to exercise. $^{17}$ Studies on somatotrophin-dependent growth factors (somatomedins) in thalassaemia major have not been reported previously. In this study the growth factor NSILAs was very low or undetectable in all 19 children with thalassaemia major. There was no evidence that the high levels of iron or ferritin in affected children were interfering with bioassay. There was no relationship of NSILAs to height centile, 6 of the children being above the 25 th centile for height. The children also failed to show the expected increase in NSILAs with age. Although NSILAs is not invariably low in all cases of short stature, ${ }^{18}$ there have been no previous reports of normal growth associated with very low levels of NSILAs. Deficiency of the growth factor NSILAs may therefore contribute to short stature in children with thalassaemia major, although other factors may permit normal growth in some affected children.

The mechanism leading to low NSILAs is not clear from this study, although mixing experiments show no evidence of inhibitory activity in thalassaemic serum. Secretion of a biologically inactive GH or a defect in the hepatic receptors for $\mathrm{GH}$ are possible mechanisms which might lead to impaired production of NSILAs. Since NSILAs is probably synthesised in the liver ${ }^{19}$ minor abnormalities in liver function tests suggest that disturbed hepatocellular function may also play a role, although other serum proteins are not affected. It is known that liver cells as well as other major organs are overloaded with iron in thalassaemia major. Iron has toxic effects on cell membrane function. ${ }^{20}$ We have studied 3 adult patients with haemochromatosis, a disorder of chronic iron accumulation. They all had undetectable circulating NSILAs (G A Werther, H G Burger, A C Herington, 1979, unpublished data). Iron toxicity may therefore be responsible for impaired NSILAs synthesis. Iron overloading in thalassaemia major is related not only to repeated blood transfusions, but also to increased intestinal absorption, a phenomenon which has been documented at the time of diagnosis in infancy. ${ }^{21}$ Iron overload may have occurred therefore even before the diagnosis of thalassaemia in affected infants. An intensive programme of iron chelation therapy is currently being undertaken in these children with the aim of lowering iron stores and reversing its possible toxic effects. If iron overload had a role in impairing NSILAs synthesis, lowering of iron stores may be expected to lead to an increase in circulating NSILAs. Another possible cause of lowered NSILAs is chronic anaemia leading to tissue hypoxia. This is less likely however, since minimum haemoglobin levels have been maintained at $8.0 \mathrm{~g} / \mathrm{dl}$ in all patients during the last 7 years.

It is recognised that some chronic diseases in children are associated with lowered somatomedins and poor growth. ${ }^{22}$ Similarly, in thalassaemia major, short stature, as well as normal stature, is associated with lowered levels of the somatomedin NSILAs. Although in some clinical conditions-for example chronic renal failure-lowered somatomedin is associated with inhibitory activity, ${ }^{23}$ this does not appear to be the mechanism in thalassaemia major. NSILAs deficiency may contribute to the growth failure in children with thalassaemia major, but other factors may permit normal growth in some affected children.

\section{Addendum}

Since this paper was submitted low levels of somatomedin, as measured by a cartilage sulphation bioassay, have been reported in children with thalassaemia major. ${ }^{24}$ Studies of the possible mechanism leading to deficiency of NSILAs have also been reported. ${ }^{25}$

We thank Janet Graham for technical assistance; Sister Dawn Johannesen, Sister Libby Reid, Sister Jan Rolls, and Sister Tricia Robertson at the Day Transfusion Centres of Queen Victoria Medical Centre and the Royal Children's Hospital, Melbourne, and the staff of the Biochemistry Department at these hospitals for help; Sue Ford, Jan Thompson, Betty Kremydas, and Pat Beggs for secretarial assistance.

Financial support was provided by the National Health and Medical Research Council of Australia.

\section{References}

1 Turner E K. Thalassaemias in Australia. Aust Fam Physician 1979; 8: 409-21.

2 Canale V C, Steinherz P, New M, Erlandson M. Endocrine function in thalassemia major. Ann NY Acad Sci 1974; 232 : 333-45. 
3 Anoussakis Ch, Alexiou D, Abatzis D, Bechrakis G. Endocrinological investigation of pituitary gonadal axis in thalassaemia major. Acta Paediatr Scand 1977; 66: 49-51.

4 McIntosh N. Endocrinopathy in thalassaemia major. Arch Dis Child 1976; 51: 195-201.

5 Flynn D M, Fairney A, Jackson D, Clayton B E. Hormonal changes in thalassaemia major. Arch Dis Child $1976 ; 51$ : $828-36$.

6 Lassman M N, O'Brien R T, Pearson H A, et al. Endocrine evaluation in thalassemia major. Ann NY Acad Sci 1974: 232: 226-37.

7 Daughaday W H, Herington A C, Phillips L S. The regulation of growth by endocrines. Annu Rev Physiol 1975; 37: 211-44.

8 Zapf J, Rinderknecht E, Humbel R E, Froesch E R. Nonsuppressible insulin-like activity (NSILA) from human serum: recent accomplishments and their physiologic implications. Metabolism 1978; 27 : 1803-28.

- Van Wyk J J, Underwood L E, Svoboda M E, et al. Somatomedin C: chemistry and biology. In: Pecile A, Muller E E, eds. Growth hormone and other biologically active peptides. International Congress Series 495. Amsterdam: Excerpta Medica, 1980: 73-80.

10 Modell B. Total management of thalassaemia major. Arch Dis Child 1970; 52: 489-500.

11 Tanner J M, Whitehouse $R$ H. Height and weight standard charts: 1975. Charts available from Creaseys of Hertford Limited, Castlemead, Hertford SG14 1LH.

12 Tanner J M, Goldstein H, Whitehouse R H. Standards for children's height at ages 2-9 years allowing for height of parents. Arch Dis Child 1970; 45: 755-62.

13 Franklin R C, Rennie G C, Burger H G, Cameron D P. $A$ bioassay for NSILA-s in individual serum samples and its relationship to somatotropin. J Clin Endocrinol Metab 1976; 43: 1164-9.

14 Zapf J, Schoenle E, Jagars G, Sand I, Grunwald J, Froesch E R. Inhibition of the action of non-suppressible insulin-like activity on isolated rat fat cells by binding to its carrier protein. J Clin Invest 1979; 63: 1077-84.

15 Young D S, Hicks J M. Method for the automatic determination of serum iron. J Clin Pathol 1965; 18: 98-102.
16 Megyesi K, Kahn C R, Roth J, Gorden P. Physiology of non-suppressible insulin-like activity. Endocrinology. In: James V H T, ed. Proceedings of the Fifth International Congress of Endocrinology, Hamburg 1976. International Congress Series 402-3. Amsterdam: Excerpta Medica, 1977: 173-7.

17 Wesley A W, Asher M I, Evans M C, et al. The exercise screening test for abnormalities in growth hormone secretion (abstract). Proc Endocrine Soc Aust 1979; 22: Supplement 2, 22.

18 Nevo Z, Laron Z. Growth factors. Am J Dis Child 1979; 133: 419-28.

19 Schalch D S, Heinrich V E, Draznin B, Johnson C J, Miller L L. Role of the liver in regulating somatomedin activity: hormonal effects on the synthesis and release of insulin-like growth factor and its carrier protein by the isolated perfused rat liver. Endocrinology 1979; 104: 1143-51.

20 Hunter F E, Jr, Gebicki J M, Hoffsten P E, Weinstein J, Scott A. Swelling and lysis of rat liver mitochondria induced by ferrous ions. J Biol Chem $1963 ; 238$ : 828-35.

21 O'Brien R T. Iron overload: clinical and pathologic aspects in pediatrics. Semin Hematol 1977; 14: 115-25.

22 Chochinov R H, Daughaday W H. Current concepts of somatomedin and other biologically related growth factors. Diabetes 1976; 25 : 994-1004.

23 Takano K, Hall K, Kastrup K W, et al. Serum somatomedin A in chronic renal failure. J Clin Endocrinol Metab $1979 ; 48$ : 371-6.

24 Saenger P, Schwartz E, Markenson A L, et al. Depressed serum somatomedin activity in $\beta$-thalassemia. $J$ Pediatr 1980; 96: 214-8.

25 Herington A C, Werther G A, Matthews R N, Burger H G. Studies on the possible mechanism for deficiency of nonsuppressible insulin-like activity in thalassemia major. J Clin Endocrinol Metab 1981 ; 52: 393-8.

Correspondence to $\mathrm{Dr}$ G A Werther, Medical Research Centre, Prince Henry's Hospital, St Kilda Road, Melbourne 3004, Australia.

Received 4 August 1980 